\title{
Differences of university education between China and the West
}

\author{
Qinghua Guan ${ }^{1,}$, Zhiyu Liü,b \\ ${ }^{1}$ Jilin Agriculture University, Changchun 130118, China. \\ aguanqinghua2000@126.com, b632830067@qq.com
}

\begin{abstract}
Education is the basis and foundation for the development of a nation, of which higher education is a reflection of a nation's development, as well as the future and prospects. A comparison of higher education between China and the West is made in order to find out the weakness and strength of China's higher education, which is of positive value to the improvement of higher education in China.
\end{abstract}

Keywords: China; the West; higher education; difference

\section{Introduction}

Generally, there are differences in social, cultural and educational development among countries. Therefore, each country forms its own educational system after a long period of development. There are many differences in China's educational system and that of the West. Although the difference in the structure of education is getting smaller as globalization of economy speeds up, obvious differences still exist. As we know, education not only is related to each one's future, but also plays a critical role in a nation's development. Comparison of different characteristics between China's higher education and the West is made in this paper, as well as some suggestions to the improvement of higher education in China.

\section{Comparison}

\subsection{Major structure of school}

Judging from the supervisory organization, American colleges and universities are divided into two categories: public and private. Public schools are usually founded and administrated by the state government. Private schools are mostly related to religious organizations, and board members are mostly priests. France is similar to Canada and Germany, where founding and administration of colleges and universities mainly rely on the government. However, supervision and administration of higher education is centralized in France. Higher education in the UK originated from private schools, where the government started from getting involved with compulsory education, and later took part in the development of higher education: a civilian operated to government operated process. China's education authority, after the founding of New China, is a mere copy of that of the Soviet Union, in which the governing of higher education is centralized by the state. Education in universities is administrated by the state, which makes teaching programs and education outlines. Founding, abandonment and alteration of institutions of higher education are in the hands of the state.

\subsection{The establishment of specialized course}

Higher education of each country is the idea of its economic system, which must serve the economy. The education in the West is geared up to the needs of the society, with three main functions of Western education, which are to serve the development of economy, research and education. Meanwhile, special courses and majors needed by the society are set up in Western countries. On the other hand, lack of adaptiveness in the Chinese universities is the cause of existing specialized courses for not meeting the needs of the society for a rather long period. In order to adapt to the society, most Chinese universities have begun to take transformation into account. New professional courses based on the social needs have been established in the past few years. 


\subsection{Specialties and choice of universities}

In order to adapt to the society, a number of specialties and courses are set up for the choice of students in Western countries. And students are free to choose and change their major or university based on their own interests. Whereas in China, only a few students in institutions of higher education are able to choose their majors based on their interest, but not allowed to transfer to other universities. In addition, a variety of optional courses are offered in Western universities, but compulsory courses make up the major parts in China.

\subsection{Student administration}

University students in the West, most like those of University of Nottingham, student IC in hand, can conveniently access the computer room, library, stadium and other school facilities. Students are not tied with the university closely for most activities except for teaching and learning. Most guidance provided to students come from experienced students, whose advice is taken into consideration for their future development (something like career in China), and the selection of specific categories. The selection of courses, time, location and classroom, which, of course, depend on how long it is completed, meaning each student is totally responsible for his own future development.

As for accommodation, some universities do not own many dormitories, and a large number of students stay in properties nearby. Restaurants and fast food restaurants are available in university zones, but most are run by outside management and completely independent from the university. Therefore, food and board do not fall into the responsibilities of the university.

On the other hand, instructions to students in Chinese universities for when, where, and what to learn, and even where to stay are given by school. In fact, higher education in China has its own advantages, e.g. standard administration and a more powerful concept of collectiveness. However, the room for the students' choice is very limited, under which conditions the students have no choice but accept passively the forced courses and specialties. In addition, the implementation of plans has brought heavy burdens to students, which at the same time, takes much human resource for such management.

Objectively, bad habits may develop through passive learning. If a student's personal characteristics are ignored, his enthusiasm to study may be restrained for a long time. More importantly, mechanical memorizing and stress of test scores, to a certain degree, cause weariness of study and cheating in tests, and further damage the learning atmosphere of the students and the sound progress of education environment.

\subsection{Teaching Method}

Western universities use heuristic teaching, where teachers always ask inspiring questions in class. In such an education environment, students enjoy a high degree of freedom, and are free to raise any questions. Such a vivid and invigorating teaching method brings positive atmosphere, and is good for improving the students' independent thinking and problem-solving abilities. On the other hand, the high requirements for such quality might compromise the teaching quality and the depth of learning in class.

Whereas in China, more attention is paid to systematic study in higher education, in which a teacher's course teaching have to follow certain plans. There is certain interaction between teachers and students in class, but listening to the teacher is still the main pattern. This method helps with the 
learning of systematic knowledge, as well as obtaining the details, but to the disadvantage of innovation by the students.

\subsection{Standard of Evaluation}

Instead of the abilities of memorizing and describing, abilities of analyzing and solving problems are stressed more in western universities. Mechanical memorization is not what the students need, but their utmost innovative thinking. Students can be trained and educated with learning interest and innovativeness. Therefore, the students in the West are always taught to research and create. Many creations and innovation always come out from Western universities. However, traditional teaching and learning methods are still used in Chinese universities, in which testing and mechanical memorization is essential. This examination style, as a consequence, seriously suppresses learning enthusiasm of the students, driving them to focus on segmentary and rigid theories, and neglecting practices.

Higher education, according to International Education Classification of Education (ISCED) published by UNESCO, can be divided into three levels: ISCED Level 5, not granted primary university diploma, is equivalent to junior college level in China; ISCED Level 6, granted primary university diploma, is equivalent to undergraduate university level in China; and ISCED Level 7, granted senior university diploma, is equivalent to postgraduate education in China. ISCED Level 7 in Western countries is more advanced. The world's average proportion of Levels 5, 6, and 7 in 1995 was 29, 63 and 8. Figures of several Western countries are shown in Table 1.

Table 1 Comparison of education level structure between China and the West

\begin{tabular}{cccc}
\hline country & ISCED 5 & ISCED 6 & ISCED 7 \\
\hline The United States & 39 & 47 & 14 \\
Canada & 49 & 35 & 6 \\
Australia & 40 & 47 & 13 \\
Britain & 28 & 57 & 15 \\
France & 22, & 68, & 10 \\
China & 64 & 33, & 3 \\
\hline
\end{tabular}

Table 2 Comparison of education level structure between China and the West with undergraduate education converted to 100

\begin{tabular}{cccc}
\hline country & ISCED 5 & ISCED 6 & ISCED 7 \\
\hline The United States & 83 & 100 & 30 \\
Canada & 140 & 100 & 17 \\
Australia & 85 & 100 & 28 \\
Britain & 49 & 100 & 26 \\
France & 32, & 100, & 15 \\
China & 139 & 100, & 8 \\
\hline
\end{tabular}

Comparison is made further with undergraduate university education converted into 100 for reference. The world's average level is 46, 100 and 13. Certain Western countries are shown in Table 2, from which one can draw a conclusion that the development of education level structure in 
China has a certain gap between either the world's average level, or that of developed countries.

\section{Conclusion}

Education in the West is a "try" education. Students are asked to try and experience first, to find out what the difficulties are and later solutions. During this process, students gain experience and make conclusions when trying to solve the problems, which is the knowledge and fruits that truly belong to the students. In comparison, Chinese education is more of an indoctrination style. Under this system, students are taught with formed experiences, told to follow their teacher's instructions step by step when they learn and practice, and whatever conclusions come after it are from books. The result, of course, is that they most likely are not able to jump out from the set patterns. The biggest difference of education between China and the West, is whether it is people-oriented and takes in account the ability of the students. One can say that the education in China follows "non-defective goods production" philosophy: a "perfect" education pattern in hope of producing qualified products, in which students all follow the doctrine of "no mistake is to be made in study", with their innovation thinking inhibited.

Education in China needs reform. To enhance the development of higher education, China needs to draw lessons from the Western higher education system. Meanwhile, education for all-round development needs to be considered as the most important element, taking the situation in China into account. It is essential to build up people-oriented education philosophy, keep the balance of the uniformity of the system and flexibility, improve in overall the students' involvement with teaching and learning practice, and establish a sound and diversified evaluation system, to truly show the improvement of overall quality of the students.

\section{References}

[1]. Baoxing Wang. Western education twelve. angxi Normal University Press,2004, P.46-48.

Gide E, Wu M, \& Wang X. The influlence of internationalis-ation of higher education: a China's Study. Procedia Social and Behavioral Sciences.Vol. 2(2010) No. 2, P.675-5681.

[2]. Yang Li, Zhang Tong. Quality Education in University in the Sightof Chinese and Western Culture. Journal of Yangzhou University(Higher Education Study Edition). Vol. 1(2008) No. 12, $\mathrm{P}, 8-11$ 。

[3]. Zhuwang Yuan. The difference between Chinese and western higher education development path and its influence. Higher education research. Vol. 1(1998)No.,P.20-22。

[4]. Baoming Zhang, Baokun Zhang. The gap between the development of Chinese and Western Higher Education. Jiangsu Higher Education. Vol.3(2001) No.3,P.112-115。

[5]. UNESCO (Jinde Luo translated). World Education Report. China Translation and Publishing Corporation, UNESCO, 1998. P.48-55.

[6]. 1999/2000 World Development Report. China Financial and Economic Publishing House, 2000,P108-143.

[7]. Li Zhang. the National Education Development Research Center of Chinese education. 2000 Green Paper, Education Science Publishing House , 2000,P.75-83.

[8]. Yang Ming, China's education modernization goals from far. Exploring Education Development. Vol. 8(2000) No. 8, P. 9-14. 